\title{
Effect of Service Quality and Brand Image on Repurchase Intention through Word of Mouth at Budget Hotels Airy Rooms
}

\author{
Heri Prabowo1, Widji Astuti2 ${ }^{2}$, Harianto Respati ${ }^{2}$ \\ ${ }^{1}$ PGRI University of Semarang, Jawa Tengah, Indonesia \\ ${ }^{2}$ Merdeka University of Malang, Malang, Indonesia \\ Email: heriprabowo.se.mm@gmail.com
}

How to cite this paper: Prabowo, H. Astuti, W. and Respati, H. (2020) Effect of Service Quality and Brand Image on Repurchase Intention through Word of Mouth at Budget Hotels Airy Rooms. Open Journal of Business and Management, 8, 194-207.

https://doi.org/10.4236/ojbm.2020.81012

Received: November 22, 2019

Accepted: December 20, 2019

Published: December 23, 2019

Copyright $\odot 2020$ by author(s) and Scientific Research Publishing Inc. This work is licensed under the Creative Commons Attribution International License (CC BY 4.0).

http://creativecommons.org/licenses/by/4.0/

\begin{abstract}
The study done aimed to analyze the factors that could affect repurchase intention. The study aimed to measure the effect of service quality, brand image, and word of mouth on repurchase intention. Furthermore, the study was also to measure the most dominant factors in affecting repurchase intention, both direct and indirect effects. Semarang City was chosen as a representative place because it had the lowest room occupancy level among the provincial capitals in Java Island. The result of analysis shows that service quality, brand image, and word of mouth affected repurchase intention, both directly and indirectly. The most directly affecting variable was the word-of-mouth variable, while the variable that had indirect effect through the word-of-mouth variable was brand image. The contribution of all variables studied in affecting repurchase intention was 93.7 percent, it means that there were other factors affecting repurchase intention beyond the variables studied.
\end{abstract}

\section{Keywords}

Service Quality, Brand Image, Word of Mouth, Repurchase Intention

\section{Introduction}

Association of Indonesian Hotels and Restaurants states that the growth of hospitality sector in Indonesia develops rapidly. The data show that the number of star hotels reaches 2300 hotels with the number of rooms up to 290,000 rooms, while the number of non-star hotel reaches 16,000 hotels with the number of rooms up to 285,000 rooms. In general, the hotel room occupancy rate in 2016 was 51.5\% and in $201752.22 \%$ (http://www.bps.go.id/, 2018). One of the 
cities with the biggest number of hotels is Semarang. The presence of 118 hotels with average occupancy of approximately 50\%, although it can reach $95 \%$ $100 \%$ during holiday season, is considered low and averagely every $1.9 \mathrm{~km}$ there is a hotel. While the average Length of Stay (LOS) ranges from 1.2 - 1.7 days that has not reached the ideal, namely minimum of 2 days.

The development of hospitality business nowadays is supported by the development of technology. There is a technology company that manages quality rooms with affordable price. The technology company is Airy Rooms with aim to increase profits by increase of hotel room occupancy rate. Airy Rooms is an Accommodation Network Orchestrator (ANO) partnered with the best budget hotels throughout Indonesia with support of updated technology to give the best stay experience with affordable price. The affordable price does not reduce the experience given by giving seven guarantees of comfort in Airy Rooms, among others: clean bed, free Wi-Fi, flat screen TV, AC, hot water, free bath supplies and drinking water. Five facts about Airy Rooms are among others: just entering the region or landmark in web search or Airy App, there are three choices of rooms, Airy Eco, Airy Standard, and Airy Primer, there are promos each month, typical souvenirs of Airy Rooms, free snacks and drinking water every day, in addition to guarantee for the guests staying.

The hotels incorporated in Airy Rooms are given Airy Rooms attributes with typical logo of Airy Rooms and in blue color, such as pouch of bath supplies of Airy Rooms and the installation of Airy Rooms neon box at the hotel location even though the hotel has a brand name already. Besides that, the hotels incorporated in Airy Rooms are given five benefits, among others operation facility, helping the staff to provide better service, income increase, using Airy Customer Service available for 24 hours, and allowed to sell in other Online Travel Agents (OTA) such as Traveloka, Agoda, Tiket.com, and so on.

Customer rating on Airy Rooms hotels in Semarang City shows varied values, with the lowest rating being 6.0/10 (good) and the highest 9.2/10 (excellent). It indicates rating difference, some rate positive and some rate negative. The rating is based on stay experience at the hotels incorporated in Airy Rooms. Positive rating about the service is indicated by good comment, such as friendly service, good service, quick service, responsive service, friendly and helpful receptionists and staff, excellent service. However, some also feel service not as expected, such as poor service, bad service, having to wait because the room is being tidied up, unfriendly welcomed by receptionists, considering that the front office needs training because they are unfamiliar with the application.

Impressions on the hotels incorporated in Airy Rooms are also there, it shows the formation of perception towards Airy Rooms that has its own standard. The impressions on Airy Rooms appear from customer comments saying "Standard Airy that is okay," and there are comments saying that the supplies in Airy Rooms everywhere are standardized and taken care, and some also feel disappointed by the hotel service but there is still a plus value because Airy Rooms 
addition is there. However, some give comments by comparing other Airy Rooms based on the previous experience of using Airy Rooms. The comparison occurs because there is a disappointment and it is not considered to reflect Airy Rooms such as room cleanliness, hotel appearance.

Positive experience of guests staying at the hotels incorporated in Airy Rooms brings up positive perception and affects the behavior to recommend it to other people to stay at the hotels incorporated in Airy Rooms. Nevertheless, there are also uninteresting impression and experience when staying at Airy Rooms hotels causing them to not want to recommend it to other people. Intention to come again of guests staying is marked by comments, such as guests who will order the hotel again, some also say "I may come back", some also give comments that the hotels can be the choice when they visit Semarang again. Nevertheless, there are comments of who does not want to stay at Airy Rooms hotels. The comments explain that the hotels do not give 7 guarantees promised by Airy Rooms and they conclude that they do not want to stay at Airy Rooms hotels (Traveloka's Guest Comments, 25 July 2018). The customer experience, comments, impression, and intention to come back to the hotels incorporated in Airy Rooms are the opportunity to answer customer challenge to come back to the same hotel or repurchase the products and service at the same hotel or in economic term referred to as repurchase intention. The empirical phenomenon of experience of staying guests by giving various comments and impressions telling about their experience either positive or negative is the form of word of mouth and is an external factor that is difficult to be controlled by the company.

\section{Literature Review}

Service Quality

Service quality is the extent of difference between reality and customer expectation on the service they receive/get [1]. Service quality component is conceptualized in service marketing research are that focuses on the quality perceived; defined as customer rating related to overall quality of entity. Definition of service is each action or activity that can be offered by a party to another party, which is basically intangible and does not cause any ownership. The production can be related or is not related to a physical product [2]. Service is producer behavior in order to satisfy the needs and desires of guests to achieve guest satisfaction. There are five dimensions or attributes that need to be paid attention in service quality. The first dimension is tangible form, namely the physical condition available in giving service including physical facility, supply, staff, and communication means. The tangible dimension is generally used by companies to improve their image in the eyes of guests. The second dimension is reliability, namely the ability to give service performance promised reliably and accurately. The third dimension is responsiveness, namely the desire of the staff to help the guests and give quick and accurate service. The fourth dimension is assurance, including knowledge, ability, courtesy, and trustworthiness of the staff to devel- 
op customer trust. The fifth dimension is empathy, namely individual care given by the service provider so the customers feel important, respected, and understood by the company [1].

Studies on the position of service quality variable towards other variables especially word-of-mouth and repurchase intention variable were done by previous researchers. The effect of service quality on word of mouth. The result shows that service quality affected word of mouth [3]. The effect of service quality on word of mouth [4], similarly according to [5] that shows that service quality affected word of mouth. Furthermore, similarly the study [6] that service quality affected repurchase intention. The same result is also indicated by the study by [7] that shows that service quality affected repurchase intention. Similarly, the study shows that service quality affected repurchase intention [8]. The study [9] shows that service quality affected word of mouth and repurchase intention, similarly according to [10] that states that service quality affected repurchase intention.

Brand Image

The definition of brand image image can be defined as a perception about brand as reflected by the brand association held in consumer memory [2]. From the definition, brand image is the perception about brand as reflected by the brand association held in consumer memory. Image is a concept that can be understood easily, but difficult to explain systematically because it is abstract. Brand is the symbol and quality indicator of a product. Brands of products long known by customers will be an image, even become the status of a product. According to [11], brand image is the description about association and customer belief on certain brand. While according to Shimp et al., brand image is the type of association appearing in customers' mind when they remember certain brand. The association simply can occur in form of thinking or certain brand related to a brand. Brand image can be positive or negative, depending on someone's perception on the brand. A brand can be said as successful when the buyers or the users perceive the presence of relevant, unique, and sustainable added value that fulfills their needs the most satisfactorily.

Studies on brand image were done a lot such as [12] that brand image variable is formed by indicators of very comfortable, very clean, and having different image, while according to [13], the indicators of hotel brand image are comfort, interior design, price, physical facility, interior design, and trustworthiness. Studies on brand image in affecting other variables especially word-of-mouth and repurchase intention variable were done by previous researchers. Among the studies are that by [14], the result shows that brand image affected word of mouth and repurchase intention. The study by [15] that investigated about the effect of brand image on word of mouth shows that brand image affected word of mouth. However, different result of study shows by [16] that shows that brand image did not affect word of mouth. Besides that, the study by [17] shows that brand image affected repurchase intention. The study by [18] shows that brand 
image affected repurchase intention. Similarly, the study by [19] shows that brand image affected repurchase intention.

Word of Mouth

Word of mouth is a form of written and electronic communication among people in connection with the strengths or experience of buying or using products or services [2]. Word of mouth is an activity of individuals of exchanging information, especially about good things so as to affect customer decision to buy and make business achieve success [19]. According to [2], word of mouth can be very effective for business in which customers can feel more private relationship.

A study on the effect of word of mouth on repurchase intention [20]. The result of the study shows that word of mouth affected repurchase intention. The same study was also done by [14] whose result of study shows that word of mouth affected repurchase intention. While in the study by [21], it mentions some indicators of word-of-mouth variable, namely giving recommendations, advising, and telling about positive things, similarly the study by [5] that states that service quality affected word of mouth. The study by [22] shows that word of mouth affected repurchase intention.

Repurchase Intention

Repurchase intention as customer behavior that gives positive response to the service quality received from a company and intends to revisit or consume the products of the company again. There are some factors that can affect customers in purchase intention, either internal or external factors. Internal factors from within the customers are trust and customer attitude towards products or services, while the disturbing factors from external are other people's attitude and situation of purchase place [2]. Customers will more intend to repurchase a product or service if the value offered by a product or service is excellent. The value really gives positive and interesting impression. Customers often intend to purchase because of intention along with emotion that makes purchase intention higher.

A study on repurchase intention was done by [23] entitled Customer repurchase intention: A general structural equation model. In the study, the variables used were brand preference, expected switching cost, customer loyalty, customer satisfaction, customer satisfaction, customer perceived value, perceived equity, and perceived quality. The result of the study shows that all variables used affected repurchasing intention. Repurchase intention someone's planned decision to repurchase certain services by considering the situation and level of fondness [23]. According to [2], there are some main factors that affect someone's interest to have repurchase intention, namely psychological, personal, and social. The first factor is psychological, formed by motivation, perception, learning, and belief. Conclusion that can be taken based on the definition of repurchase intention is that someone's decision to repurchase in the future motivated by satisfaction and trust can bring benefits for the company, namely that can be directly 
perceived is the company cost. The study [3] shows that the factors affecting repurchase intention were service quality, monetary price, behavior price, and word of mouth. In the study, it is mentioned that repurchase intention variable was formed by three indicators, namely the first choice, strong interest, and plan again.

Theoretical Framework and Hypotheses

The study was done with the theoretical framework as illustrated in Figure 1 by connecting the independent variables (service quality and brand image) and the dependent variables (word of mouth and repurchase intention).

Based on the theory, the result of previous relevant studies developed in the theoretical framework, the hypotheses in the study are as the following:

$\mathrm{H} 1$ : Service quality and brand image have positive and significant effect on word of mouth.

$\mathrm{H} 2$ : Service quality, brand image, and word of mouth have positive and significant effect on repurchase intention.

H3: Word of mouth has positive and significant effect on repurchase intention.

H4: Service quality and brand image have positive and significant effect on repurchase intention through word of mouth.

\section{Methodology}

The study was done using quantitative research method, namely a research method based on the philosophy of positivism, used to investigate on a certain population or samples, the data collection used assessment instrument, the data analysis was quantitative/statistical, aiming to test the hypotheses specified. The instrument used was questionnaire distributed to the respondents. The population of the study was the guests staying at the hotels incorporated in Airy Rooms, while the number of samples was 191 respondents obtained from the calculation of Slovin's formula based on average staying guests in each day at the hotels incorporated in Airy Rooms. The collected date were then analyzed using a program called Analysis of Moment Structure (AMOS) version 22.

\section{Results and Findings}

\section{Characteristics of Respondents}

The characteristics of respondents based on length of stay are presented in Table 1 as follows:

Table 1 shows that the most length of stay at Airy Rooms hotels is one day one night, with percentage out of all respondents of $80.5 \%$, while in the second position is staying for two days two nights, namely for $18.8 \%$, then three days three nights for $0.55 \%$. Furthermore, the characteristics of respondents based on purpose of staying at Airy Rooms hotels are presented in Table 2 as follows:

The result shows that the purpose of staying of the respondents is mostly for vacation, namely $49.7 \%$, followed by official duty for $45 \%$, and business purpose for $5.2 \%$. 


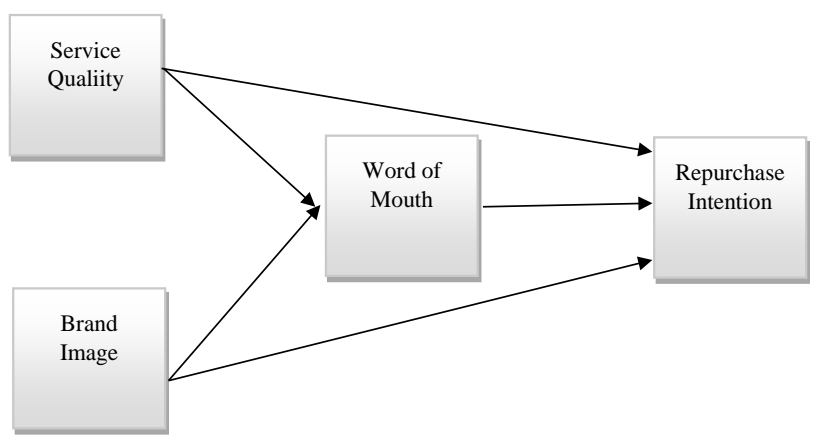

Figure 1. Suggested research model.

Table 1. Length of stay of airy rooms guests.

\begin{tabular}{rcc}
\hline Length of Stay & Number & Frequency \\
\hline 1 day 1 night & 154 & $80.5 \%$ \\
2 days 2 nights & 36 & $18.8 \%$ \\
3 days 3 nights & 1 & $0.5 \%$ \\
\hline
\end{tabular}

Table 2. Purpose of staying of airy rooms guests.

\begin{tabular}{ccc}
\hline Purpose of Staying & Number & Frequency \\
\hline Business & 10 & $5.3 \%$ \\
Vacation & 95 & $49.7 \%$ \\
Official Duty & 86 & $45.0 \%$ \\
\hline
\end{tabular}

\section{Result of Testing of Structural Equation Model}

Testing of SEM assumption obtained result of absence of normality, outliner, and multicollinearity problem, it can be concluded that it fulfilled the requirement to be experimented on structural equation model of the study using tool of AMOS (Analysis Moment of Structure). The result of overall model testing is presented in Figure 2 as follows:

The result of overall model analysis in the study was compared to the cutoff value of each criteria of goodness of fit presented in Table 3 as follows:

Table 3 shows that the result of structural model shows the value of goodness-of-fit criteria for chi-square, significance probability, CMIN/DF, RMSEA, TLI, NFI, and PNFI fulfilled the requirements so it could be concluded that the model was good.

Factor loading analysis was done on each variable indicator to ensure whether the variable indicator could form and operate the variables presented in Table 4 as follows:

Table 4 shows that the value of each indicator fulfilled the convergent validity, namely above 0.50 , the result could be concluded that the indicators formed the variables studied. The result of data analysis for hypothesis testing is presented in Table 5 as follows:

Table 4 shows that service quality and brand image variables had greater CR 
and the value of p-value $\leq 0.05$ namely 0.017 and 0.03 . The value of standardized regression weight of service quality variable was 0.391 and brand image variable was 0.478. Based on the data of values above, it could be concluded that the First Hypothesis was accepted, it means that service quality and brand image had positive and significant effect on word of mouth. Then, service quality and brand image variables had CR greater than 2 and the value of $\mathrm{p}$-value $\leq 0.05$ namely service quality for 0.48 and brand image for 0.49 . The value of standardized regression weight of service quality variable was 0.281 and brand image variable was 0.279 . Based on the data of values above, it could be concluded that the second hypothesis was accepted, it means that service quality and brand image had positive and significant effect on repurchase intention. Then, word-of-mouth variable had CR greater than 2 , and the value of $\mathrm{p}$-value $\leq$ 0.05 namely 0.002 and the value of standardized weight was 0.480 . Based on the data of values above, it could be concluded that the third hypothesis was accepted, it means that word of mouth had positive and significant effect on repurchase intention. The fourth testing analysis was whether service quality and brand image had effect on repurchase intention through word of mouth. The result of data analysis for testing of the fourth hypothesis is presented in Table 6 as follows:

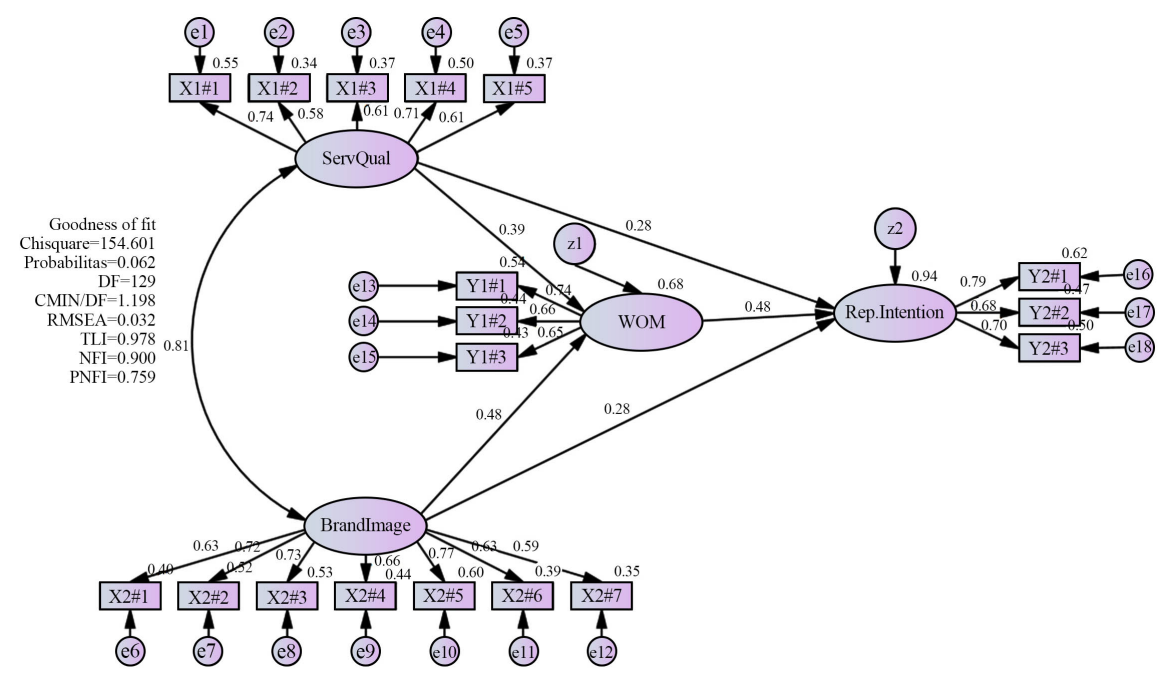

Figure 2. SEM Analysis using AMOS program.

Table 3. Result of model test.

\begin{tabular}{cccc}
\hline Goodness of Fit Index & Cutoff Value & Result & Evaluation \\
\hline X2 Chi-Square & X2 with df; 129; p: 5\%=156.508 & 154.601 & Good \\
Significance Probability & $\geq 0.05$ & 0.062 & Good \\
CMIN/DF & $\leq 2.00$ & 1.198 & Good \\
RMSEA & $\leq 0.08$ & 0.032 & Good \\
TLI & $\geq 0.90$ & 0.978 & Good \\
NFI & $\geq 0.90$ & 0.900 & Good \\
PNFI & $\geq 0.60$ & 0.759 & Good \\
\hline
\end{tabular}


Table 4. Value of factor loading of variable indicator.

\begin{tabular}{|c|c|c|}
\hline Variable & Indicator & Factor Loading \\
\hline \multirow[t]{5}{*}{ Service Quality } & Tangibles & 0.742 \\
\hline & Reliability & 0.584 \\
\hline & Responsiveness & 0.607 \\
\hline & Assurance & 0.706 \\
\hline & Empathy & 0.609 \\
\hline \multirow[t]{7}{*}{ Brand Image } & Comfort & 0.629 \\
\hline & Exterior Design & 0.723 \\
\hline & Price & 0.727 \\
\hline & Physical Facility & 0.664 \\
\hline & Interior Design & 0.773 \\
\hline & Trustworthiness & 0.628 \\
\hline & Location & 0.594 \\
\hline \multirow[t]{3}{*}{ Word of Mouth } & Recommending & 0.738 \\
\hline & Advising & 0.662 \\
\hline & Telling about positive things & 0.653 \\
\hline \multirow[t]{3}{*}{ Repurchase Intention } & First choice & 0.789 \\
\hline & Strong interest & 0.685 \\
\hline & Plan again & 0.704 \\
\hline
\end{tabular}

Table 5. Result of structural equation modeling for hypothesis testing.

\begin{tabular}{cccc}
\hline Research Variable & Standardized Regression Weight & C.R. & P \\
\hline Service Quality $\rightarrow$ Word of Mouth & 0.391 & 2.398 & 0.017 \\
Brand Image $\rightarrow$ Word of Mouth & 0.478 & 2.951 & 0.003 \\
Service Quality $\rightarrow$ Repurchase Intention & 0.281 & 1.977 & 0.048 \\
Brand Image $\rightarrow$ Repurchase Intention & 0.279 & 1.968 & 0.049 \\
Word of Mouth $\rightarrow$ Repurchase Intention & 0.480 & 3.124 & 0.002 \\
\hline
\end{tabular}

Table 6. Analysis of direct and indirect effect for test of the fourth hypothesis.

\begin{tabular}{llll}
\hline Variable & Direct Effect & Indirect Effect & Total Effect \\
\hline $\begin{array}{l}\text { Service Quality on Repurchase } \\
\text { Intention through Word of Mouth }\end{array}$ & 0.281 & 0.188 & 0.469 \\
$\begin{array}{l}\text { Brand Image on Repurchase Intention } \\
\text { through Word of Mouth }\end{array}$ & 0.279 & 0.230 & 0.509 \\
\hline
\end{tabular}

Table 6 shows that the direct effect of service quality on repurchase intention was 0.281 and the indirect effect of service quality on repurchase intention was 0.188 with total effect of service quality on repurchase intention through word of mouth was 0.469 , while the direct effect of brand image on repurchase intention 
was 0.279 and the indirect effect of brand image on repurchase intention was 0.230 , while the total effect of brand image on repurchase intention was 0.509 . The significance level of track can be observed from the output text of Table 5 and Table 6 that shows that all values of $\mathrm{p}<0.05$ that means that all were significant. The result of analysis shows that the total effect was greater than the direct effect, therefore it could be concluded that the fourth hypothesis was accepted that means that service quality and brand image had positive and significant effect on repurchase intention through word of mouth.

\section{Discussions and Conclusions}

Service quality and brand image had positive and significant effects on word of mouth at the hotels incorporated in Airy Rooms. Service quality and brand image had positive and significant effects on word of mouth at the hotels incorporated in Airy Rooms where brand image was the dominant factor in giving effect on word of mouth. Brand image was formed from impression of very comfortable, very clean, conforms to the class, excellent, different image, trustworthy, and quality. Different images gave the biggest contribution in forming brand image. Different images were illustrated as Airy Rooms hotels that had typical attributes and the service received was according to the price paid. Service quality was formed tangibles, reliability, responsiveness, assurance, and empathy. Tangibles gave the biggest contribution in forming service quality that means that the guests staying at Airy Rooms hotels saw direct proof in form of physical facilities such as maintained building and adequate parking lot. Word of mouth was in form of recommending, advising, and telling about positive things. The biggest contribution of word of mouth was recommending reflected by cost saving, choose Airy Rooms hotels and when you travel in group, choose Airy Rooms.

Service quality and brand image had effects on word of mouth. The finding shows that the guests staying at Airy Rooms hotels seeing direct proof in form of physical facilities such as maintained building and adequate parking lot and Airy Rooms hotels having typical attributes and the service received according to the price paid were the reasons in recommending in form of cost saving, choose Airy Rooms hotels and when you travel in group, choose Airy Rooms. The result of study shows that service quality on word of mouth had similarity to the finding [3] [4] and [5] that concluded that service quality had effects on word of mouth. In the study, besides word of mouth, another factor that gave effect was brand image. The effect of brand image on word of mouth had similarity to the result of study by [14] and [24] that concluded that brand image had effects on word of mouth.

Service quality and brand image had positive and significant effects on repurchase intention. The hotels incorporated in Airy Rooms where service quality was the dominant factor in giving effects on repurchase intention. Service quality was formed tangibles, reliability, responsiveness, assurance, and empathy. Tangibles gave the biggest contribution in forming service quality that means 
that the guests staying at Airy Rooms hotels saw direct proof in form of physical facilities such as maintained building and adequate parking lot. Brand image was formed from impression of very comfortable, very clean, conforms to the class, excellent, different image, trustworthy, and quality. Different images gave the biggest contribution in forming brand image. Different images were illustrated as Airy Rooms hotels that had typical attributes and the service received was according to the price paid. Repurchase intention was formed by the first choice, strong interest, and plan again. The first factor became the dominant factor in forming repurchase intention reflected as the first choice of staying again and the first place headed to stay was Airy Rooms.

Service quality and brand image had positive and significant effect on repurchase intention. The finding shows that the guests staying at Airy Rooms hotels seeing direct proof in form of physical facilities such as maintained building and adequate parking lot and Airy Rooms hotels having typical attributes and the service received according to the price paid made the first choice to stay again and the place headed to stay was Airy Rooms. The effect of service quality on repurchase intention had similarity to the study by [6] and [21] that concluded that service quality had effect on repurchase intention. Brand image having effect on repurchase intention had similarity to the study by [25] that concluded that brand image had effect on repurchase intention.

Word of mouth had positive and significant effect on repurchase intention at the hotels incorporated in Airy Rooms. Word of mouth was in form of recommending, advising, and telling about positive things. The biggest contribution of word of mouth was recommending reflected by cost saving, choose Airy Rooms hotels and when you travel in group choose Airy Rooms. Repurchase intention was formed by the first choice, strong interest, and plan again. The first factor became the dominant factor in forming repurchase intention reflected as the first choice of staying again and the first place headed to stay was Airy Rooms.

Word of mouth had positive and significant effect on repurchase intention at the hotels incorporated in Airy Rooms. The finding shows recommending reflected by cost saving, choose Airy Rooms hotels and when you travel in group choose Airy Rooms and the first choice of staying again and the first place headed to stay was Airy Rooms. The result of study had similarity to the study by [3] [14], and [20] that shows that word of mouth had effect on repurchase intention.

Service quality and brand image had positive and significant effect on repurchase intention through word of mouth at the hotels incorporated in Airy Rooms. Service quality was formed tangibles, reliability, responsiveness, assurance, and empathy. Tangibles gave the biggest contribution in forming service quality that means that the guests staying at Airy Rooms hotels saw direct proof in form of physical facilities such as maintained building and adequate parking lot. Brand image was formed from impression of very comfortable, very clean, conforms to the class, excellent, different image, trustworthy, and quality. Different images gave the biggest contribution in forming brand image. 
Different image was illustrated as Airy Rooms hotels that had typical attributes and the service received was according to the price paid. Word of mouth was in form of recommending, advising, and telling about positive things. The biggest contribution of word of mouth was recommending reflected by cost saving, choose Airy Rooms hotels and when you travel in group choose Airy Rooms. Repurchase intention was formed by the first choice, strong interest, and plan again. The first factor became the dominant factor in forming repurchase intention reflected as the first choice of staying again and the first place headed to stay was Airy Rooms.

Service quality and brand image had positive and significant effect on repurchase intention through word of mouth. The finding shows that the guests staying at Airy Rooms hotels saw direct proof in form of physical facilities such as maintained building and adequate parking lot and Airy Rooms hotels that had typical attributes and the service received was according to the price paid that could made as the first choice to stay again and the place headed to stay was Airy Rooms in which the experience became the basis in giving recommendation with recommendation of cost saving, choose Airy Rooms hotels and when you travel in group choose Airy Rooms. The effect of service quality on repurchase intention through word of mouth had similarity to the study by [3] and the effect of brand image on repurchase intention through word of mouth had similarity to the study by [14].

\section{Limitation}

It needs to develop conception in model for repurchase intention determined by the role of word of mouth. Future research and scientific development shall be done by considering the limitations of the study. From the result of analysis, the squared multiple correlation coefficient of Word of Mouth was 0.685 that means that Service Quality and Brand Image only gave $68.5 \%$ and the rest $31.5 \%$ was affected by other variables beyond the study. Similarly, the squared multiple correlation coefficient of Repurchase Intention was 0.937 that means that Service Quality, Brand Image, and Word of Mouth only gave $93.7 \%$ on Repurchase Intention and the rest $6.7 \%$ was affected by other variables beyond the study. A variable that can be added in future research is Customer Satisfaction with consideration of the importance of giving trust to customers that Brand Image or Service Quality gives level of trust that the products or services bought can satisfy the needs and have added value after the customers use the products or services.

\section{Conflicts of Interest}

The authors declare no conflicts of interest regarding the publication of this paper.

\section{References}

[1] Parasuraman, A., Zeithaml, V.A. and Berry, L.L. (1985) A Conceptual Model of Service Quality and Its Implications for Future Research. The Journal of Marketing, 
49, 41-50. https://doi.org/10.1177/002224298504900403

[2] Kotler, P. and Dan Lane Keller, K. (2016) Manajemen Pemasaran, Edisi Kelima Belas. Erlangga, Jakarta.

[3] Liu, C.H.S. and Lee, D.T. (2016) Service Quality and Price Perception of Service: Influence on Word-of-Mouth and Revisit Intention. Journal of Air Transport Management, 52, 42-54. https://doi.org/10.1016/j.jairtraman.2015.12.007

[4] Aljumaa, A. (2014) Investigating the Mediating Effect of Customer Satisfaction in the Service Quality-Word of Mouth Relationship. International Journal of Business and Management Invention, 3, 40-44.

[5] Rahayu, S. (2011) Internal Customer Satisfaction and Service Quality toward Trust and Word of Mouth. ASEAN Marketing Journal, 3, 114-123. https://doi.org/10.21002/amj.v3i2.2026

[6] Srivastava, K. and Sharma, N.K. (2013) Service Quality, Corporate Brand Image, and Switching Behavior: The Mediating Role of Customer Satisfaction and Repurchase Intention. Services Marketing Quarterly, 34, 274-291. https://doi.org/10.1080/15332969.2013.827020

[7] Haryono, S., Suharyono, Achmad Fauzi, D.H. and Dan Iman, S. (2015) The Effects of Service Quality on Customer Satisfaction, Customer Deliaghy, Trust, Repurchase Intention and Word of Mouth. European Journal of Business and Management, 7, 36-48.

[8] Kadang, H. and dan Sukati, I. (2012) A Study of Service Quality: An Empirical Investigation of Indonesian Airlines Service. South East Asian Journal of Contemporary Business, Economics and Law, 1, 101-107.

[9] Samad, A. (2014) Examining the Impact of Perceived Service Quality Dimensions on Repurchase Intentions and Word of Mouth: A Case from Software Industry of Pakistan. IOSR Journal of Business and Management, 16, 37-41. https://doi.org/10.9790/487X-16133741

[10] Saleem, M.A.S. and Yaseen, Z.D.A. (2017) Impact of Service Quality and Trust on Repurchase Intention-The Case of Pakistan Airline Industry. Asia Pacific Journal of Marketing and Logistics, 29, 1136-1159. https://doi.org/10.1108/APJML-10-2016-0192

[11] Tjiptono, F. (2008) Strategi Pemasaran. Andi Offset, Yogyakarta.

[12] Lahap, J., Ramli, N.S., Said, N.M., Radzi, S.M. and Zain, R.A. (2016) A Study of Brand Image towards Customer's Satisfaction in the Malaysian Hotel Industry. Procedia-Social and Behavioral Sciences, 224, 149-157. https://doi.org/10.1016/j.sbspro.2016.05.430

[13] Kandampully, J. and Suhartanto, D. (2000) Customer Loyalty in the Hotel Industry: The Role of Customer Satisfaction and Image. International Journal of Cotemporary Hospitality Management, 12, 346-351. https://doi.org/10.1108/09596110010342559

[14] Anggaraini, M., Farida, N. and Listyorini, S. (2015) Pengaruh Perceived Value dan Brand Image Terhadap Repurchase Intention Melalui Word of Mouth Sebagai Variabel Intervening Smartphone Samsung Galaxy Series. Diponegoro Journal of Social and Political of Science, 4, 1-9.

[15] Shakeri, S. and Alavi, H.H. (2016) Investigating the Impact of Brand Love, Brand Image, Excitement and Word of Mouth on Consumers. International Journal of Information Research and Review, 3, 3081-3085.

[16] Ismail, A.R. and Spinelli, G. (2012) Effects of Brand Love, Personality and Image on 
Word of Mouth: The Case of Fashion Brands among Young Consumers. Journal of Fashion Marketing and Management: An International Journal, 16, 386-398. https://doi.org/10.1108/13612021211265791

[17] Ranjbarian, B., Sanayei, A. and Kaboli, M.R. (2012) An Analysis of Brand Image, Perceived Quality, Customer Satisfaction and Re-Purchase Intention in Iranian Department Stores. International Journal of Business and Management, 7, 40-48. https://doi.org/10.5539/ijbm.v7n6p40

[18] Chen, H.-S. and Hsieh, T. (2011) A Study of Antecedents of Customer Repurchase Behaviors in Chain Store Supermarkets. Journal of International Management Studies, 6, 1-11.

[19] Arumsari, R. and Ariyanti, M. (2017) The Effect of Electronic Word of Mouth, Brand Image, Customer Trust and Customer Satisfaction towards Repurchase Intention at PT. GO-JEK Indonesia. International Journal of Science and Research, 6, 1732-1737. https://doi.org/10.21275/ART20175247

[20] Kitapcia, O., Akdoganb, C. and Dortyolb, İ.T. (2014) The Impact of Service Quality Dimensions on Patient Satisfaction, Repurchase Intentions and Word-of-Mouth Communication in the Public Healthcare Industry. Procedia-Social and Behavioral Sciences, 148, 161-169. https://doi.org/10.1016/j.sbspro.2014.07.030

[21] Jalilvand, M.R. and Heidari, A. (2017) Comparing Face-to-Face and Electronic Word-of-Mouth in Destination Image Formation. Information Technology \& People, 30, 710-734. https://doi.org/10.1108/ITP-09-2016-0204

[22] Söderlund, M. (2000) Customer Satisfaction, Word-of-Mouth Intentions, and Repurchase Intentions: An Empirical Exploration of the Potential for Timing-of-Measurement Effects. 29th EMAC Conference, Rotterdam.

[23] Hellier, P.K., Geursen, G.M., Carr, R.A. and Rickard, J.A. (2003) Customer Repurchase Intention: A General Structural Equation Model. European Journal of Marketing, 37, 1762-1800. https://doi.org/10.1108/03090560310495456

[24] Adilla Anggraeni, R. (2015) Effect of Brand Love, Personality and Image on Word of Mouth; the Case of Local Fashion Brand among Young Consumers. Procedia-Social and Behavioral Sciences, 211, 442-447. https://doi.org/10.1016/j.sbspro.2015.11.058

[25] Ayutthaya, S.S.N. (2013) Impact of Perceived Service on Brand Image and Repurchase Intentions of Thai Passengers towards Low Cost Carriers. AU Journal of Management, 11, 46-56. 